\title{
Enabling factors for the competitiveness of the Portuguese automotive industry
}

\author{
Luis FONSECA \\ ISEP -P. Porto and CIDEM R\&D, Porto, Portugal \\ Imf@isep.ipp.pt \\ Jorge FERNANDES \\ ISEP -P. Porto, Porto, Portugal \\ jorgelffernandes@hotmail.com \\ Sandra RAMOS \\ ISEP -P. Porto, Porto, Portugal \\ sfr@isep.ipp.pt
}

\begin{abstract}
The Portuguese automotive industry is a relevant activity sector for the Portuguese society and economy, both in job creation and value-added generation, contributing to the country's economic development. The automotive is a high challenge industry, with intense competition, a high number of brands, increased number of models and vehicles, tighter regulatory requirements (e.g., emissions), and the need to manage global supplier networks. To succeed in such a highly complex and interconnected industry requires firms to be globally competitive since most of the production of this industry is destined for the rest of the world through export. This research aims to investigate the factors that contribute to value creation and competitiveness of the Portuguese automotive industry. Following the literature review of competitive advantage theories, quantitative research was done through an online questionnaire with Portuguese auto industry firms, to validate the proposed research hypotheses. The statistical analysis of the results, based on the application of descriptive statistics methodologies, principal components analysis, and correlation analysis, allowed to conclude that in this industry sector, the adoption of a strategy of differentiation/focalization and the external context influence value creation. However, it was not possible to conclude if the specific characteristics of the organization influences, or not, the creation of value. From the theoretical point of view, the conclusions demonstrate the relevance of the adoption of a strategy of differentiation and focalization and the external context for the competitiveness of these firms, supporting the assumptions of Porter's Industry Based Theory and Generic strategies. From the practical point of view, the results highlight the importance of monitoring the external context and investing in research and development, brand image and market expertise, with the aim of enhancing the value creation and competitiveness of the components, tools, and services providers firms of the Portuguese automotive sector.
\end{abstract}

Keywords: automotive industry, competitive strategy, competitiveness, value creation, Portugal.

\section{Introduction}

With more than 72 million units produced in 2014 (Worldwatch, 2017), the automotive industry as a strong global footprint and is of significant relevance for the dynamization of the world economy, by proving mobility for people, products, components and materials with great flexibility. 
The automotive comprehends, in addition to the conventional car, the truck, the tractor, the motorcycle and a whole series of automotive equipment. Consistent with other developed countries, this sector assumes a significant relevance in Portugal, with four active 4 car manufacturers plants (ACAP, 2016). The automotive suppliers' proportion of value added to worldwide automobile manufacture shows consistent growth, from $56 \%$ in 1985 to 82\% in 2015 (Statista, 2016). In Portugal, there is a robust automotive component industry, that represents $7 \%$ of the total employment within the manufacturing industry (46.500 jobs) and contributes to $5 \%$ of the Portuguese GDP with 7.6 billion euros in exports (AFIA, 2017). This investigation aims to research what are the enabling factors for the competitiveness of the Portuguese automotive industry to enhance its competitiveness.

A robust competitive intensity characterizes the automotive industry. This is due to the competition within companies, the existence of many brands with an ever-increased number of models and vehicles, the tightening of the regulatory requirements (e.g., emissions), and the global dimension of its supplier networks, therefore, only highly competitive companies can survive in such a complex and challenging environment (Fonseca \& Domingues, 2017a).

The purpose of this investigation is to identify the factors that contribute to value creation and competitiveness of the Portuguese automotive industry. The next sections are organized as follows. The literature review section provides a brief review of the competitive strategy theories and previous research addressing the competitiveness of Portuguese automotive industry. The next section introduces the research methodology that was supported by an online questionnaire with Portuguese auto industry firms and the subsequent statistical analysis of the results (descriptive statistics methodologies, principal components analysis, and correlation analysis). The findings of the investigation are presented in the Results and discussions section with a systematic discussion of the results and identification of the theoretical and practical implications as well as limitations and future research directions. Concisely, the conclusions of this investigation highlight that for the Portuguese automotive industry sector, the external context and the adoption of a strategy of differentiation/focalization are relevant for value creation and enhancing firms' competitive position.

\section{Literature review \\ Major Competitive Strategies}

The notion of competitive strategy is related to the value creation strategy of an organization that its competitors are not able to replicate or can do it only with high costs (Porter, 1985).

The literature suggests that the success of a specific industry in a country depends heavily on the national competitiveness of that country (Porter, 1990). The national competitiveness of a country is a measure of the country's relative ability to create and maintain an environment for business to operate and thus increase the level of prosperity (Kao et al., 2008). Due to the increase in the economic, political, technological, sociocultural, ecological and demographic changes, industrial competitiveness has become more closely linked to the country's global competitiveness (Ulengin, Onsel, Aktas, Kabak, \& Ozaydın, 2014). 
According to Porter Market Industry and Generic Strategies (Porter, 1985), there are three basic generic strategies that organizations can adopt in their quest to achieve competitive advantage:

- Volume generic strategy where high production and sales volumes bring low costs competitive advantages, due to an economy of scale and learning effects;

- Differentiation generic strategy where organizations due to research and effective product development, supported by a superior brand image, can increase their value proposition and offer their products or services at higher prices than its competitors.

- Focalization generic strategy that implies focusing on specific niche markets and their unique customer needs, by developing unique low-cost (volume) or well specified and high valued products for the market (differentiation), generating strong customer loyalty and obstacles to competitors.

Several researchers have investigated the topic of competitiveness. According to Oral \& Reisman (1988), the competitiveness of manufacturers is dependent on their industrial competence, cost superiority, and economic and political environment. Firms must, therefore, establish a set of priorities such as selling price, production quality, delivery time, product range and flexibility (Demeter, 2003), or design and produce superior products than those made available by competitors (Lee \& Wilhelm, 2010). Geographic distance also plays an essential role in logistics, since the location of supplier factories in the vicinity of OEM assembly lines has become an important competitive factor (Lucato, Juníor, Vanalle, \& Arantes, 2012).

Additionally, researchers have highlighted that organizations located in economies with sophisticated financial markets have easier access to the capital need for their investments (Sala-i-Martin, et al., 2012). Also, companies that can cluster around a significant Original Equipment Manufacturer (OEM) achieve higher competitiveness than those that are not part of the cluster (Lee \& Wilhelm, 2010).

More recently, Fonseca and Domingues (2017a) have concluded that the monitoring of the organizational context (internal and external) and the capacity of organizations to manage change are relevant dimensions for the creation of value in the automotive industry at a global level.

In summary, the enabling factors for the competitiveness of the Portuguese automotive industry can be related with a) the firms own generic strategy; b) some specific characteristics of each organization; and c) the external context into which they operate. These are the primary hypothesis that this investigation will aim to address.

\section{Methodology}

Based on the literature review, the following research themes have been identified, as presented in table 1.

Table 1. Research Themes and Model components

\begin{tabular}{|l|ll|}
\hline \multicolumn{1}{|c|}{ Research Theme } & \multicolumn{1}{|c|}{ Research Model component } \\
\hline $\begin{array}{l}\text { Which strategy (s) and specific characteristics are in } \\
\text { place in the organization? }\end{array}$ & $\bullet \quad$ Construct 1. Internal Context (p1 to p12) \\
& $\bullet \quad$ Construct 1.1. Strategy (p1 to p5) \\
\hline
\end{tabular}




\begin{tabular}{|l|l|}
\hline & $\begin{array}{l}\text { Construct 1.2 Specific Characteristics (p6 to } \\
\mathrm{p} 12)\end{array}$ \\
\hline $\begin{array}{l}\text { What is the influence of the market environment for } \\
\text { the organization success? }\end{array}$ & $\begin{array}{l}\text { Construct 2. External Context (p13 to p17) } \\
\text { - Construct 2.1 Market Environment (p12 to } \\
\text { p17) }\end{array}$ \\
\hline $\begin{array}{l}\text { What are contributions due to the organizational } \\
\text { background to the Performance and to Value } \\
\text { Creation and Competitive Advantage? }\end{array}$ & - $\begin{array}{l}\text { Construct 3: Organization Performance (p18 } \\
\text { to p26) }\end{array}$ \\
\hline
\end{tabular}

Source: Authors' own research

These research themes were addressed with five automotive industry managers experts and resulted in the choice of the following three research questions:

- H1: Strategy influences Value Creation;

- H2: The Specific Characteristics of the organization influence Value Creation:

- H3: The External Context influences Value Creation.

The research methodology was designed taking into consideration the links between the original research questions, the collection of information and the conclusions that can be obtained (Ghauri \& Gronhaug, 2002). Since it was not possible to use data existing data, a survey was designed to support this quantitative research, taking into consideration the literature review and the research questions. The research instrument adopted a similar structure from those instruments reported in previous studies (Fonseca \& Domingues, $2017 \mathrm{a}, 2017 \mathrm{~b}$ ) and it was pre-tested with five automotive industry managers expert. The construct reliability was tested and validated with Cronbach Alpha greater than 0.5, in line with Davis (1964) for groups of 25-50 individuals.

The survey structure encompassed four major groups of questions addressing the following main themes: Strategy (questions P1 to P5), specific characteristics of the organization (questions P6 to P11), environment (questions P12 to P17) and performance (questions P 18 to P26). The survey questions are presented in table 2.

Table 2. Survey questions

\begin{tabular}{|l|l|}
\hline \multicolumn{1}{|c|}{ Construct } & \multicolumn{1}{|c|}{ Question } \\
\hline Strategy - Our competitive & P1 - cost minimization \\
strategy is based on ... & P2 - product/service value \\
& P3 - product/market specialization \\
& P4 - introduction of new product/services \\
P5- product/service value at minimum cost
\end{tabular}

DOI: 10.2478/picbe-2019-0002, pp. 1-12, ISSN 2558-9652| Proceedings of the $13^{\text {th }}$ International Conference on Business Excellence 2019 


\begin{tabular}{|l|l|}
\hline & $\begin{array}{l}\text { P11 - Do you consider the clusters of the Portuguese automotive } \\
\text { industry to be critical factors for its competitiveness? }\end{array}$ \\
\hline Environment & P12 - The degree of competition to which we are subject has increased \\
P13 - Instability has increased in our sector of activity \\
P14 - Our business sector has grown \\
P15 - There have been significant technological changes in our industry \\
P16 - We have an optimistic expectation regarding the evolution of the \\
business/activities of our organization \\
P17 - The distance (logistic costs) between us and the customers affects \\
our competitiveness
\end{tabular}

PICBE | 5 Source: Authors' own research.

The statistical analysis of the collected data was performed in two phases. In a first step, descriptive statistics techniques were applied to summarize the most relevant information. Since the number of variables under study was high, PCA technique - major component analysis (Pearson, 1901; Rao, 1964; Gower, 1967; Jeffers, 1967; Hotelling, 1993) was conducted to reduce the dimensionality of the data set. Given that the variables under study are all an ordinal nature, prior to conducting the PCA, a category quantification technique based on the Ridits Method (Bross, 1958) was applied, which enabled the availability of quantitative data for the PCA. This technique aims to transform a set of correlated variables into a smaller set of independent variables, the main components, which simplifies the treatment of the data. The following three steps were carried out for the PCA: 1- Validation of the ACP model (Kaiser-Meyer-Olkin- KMO index above 0.5; Aaker, Kumar, \& Day, 2001); 2- Extraction of the main components (extract all components with an eigenvalue greater than 1, Kaiser rule); 3- Internal consistency test with Cronbach Alpha (Cronbach, 1951).

In a second phase, a technique of statistical inference was applied, namely, correlation analysis based on the CPA extracted components, to test the hypotheses of investigation formulated and presented previously. Shapiro \& Wilk test (Shapiro \& Wilk, 1965) was applied to check the normality of the distribution and to decide if the correlation analysis should be made with the Pearson coefficient (if variables have normal distribution and linear relations) or Spearman coefficient (that can be used for non-normal variables or variables on 
an ordinal scale). The criteria presented in table 3 was applied to classify the correlation level (Hinkle, Wiersma, \& Jurs, 2003).

Table 3. Correlation levels classification

\begin{tabular}{|l|l|}
\hline \multicolumn{1}{|c|}{ Correlation coefficient } & \multicolumn{1}{c|}{ Correlation Level } \\
\hline 0.9 to $1(-0.9$ to -1$)$ & Very strong positive (negative) correlation \\
\hline 0.7 to $0.9(-07$ to -0.9$)$ & Strong positive (negative) correlation \\
\hline 0.5 to $0.7(-0.5$ to -0.7$)$ & Moderate positive (negative) correlation \\
\hline 0.3 to $0.5(-0.3$ to -0.5$)$ & Weak positive (negative) correlation \\
\hline 0.0 to $0.3(0$ to -0.3$)$ & Inexistent correlation \\
\hline
\end{tabular}

The tests with a p-value of less than $5 \%$ were considered significant, and the statistical SPSS Statistics Version 20 software was applied for the statistical analysis.

\section{Results and discussions}

The results of the descriptive statistics highlight that the metalworking (33\%), plastics (25\%) and mols and tools (8\%) were the major industry sectors represented in the 27 valid responses gathered through the online survey. Most (70\%) organizations have been active for more than 20 years, while "new" ones (less than 5 years) accounted for 7\%. The sample was homogenously distributed concerning company size with micro, small and medium companies. As expected for auto industry firms (Fonseca and Domingues, 2017), 96\% of the firms were ISO 9001 certified.

Concerning the demographic characteristics of the respondents, $70 \%$ held top management positions and while $26 \%$ were middle managers. There were only $7 \%$ of the respondents with age below 30 years, while 15\% were between 30 and 40 years, 67\% between 40 and 55 and 11\% above 55 years old. Of these respondents, 56\% were for more than 10 years in the organization, $15 \%$ between 5 and 10 years and 30\% less than 5 years.

The overall distribution of the answers for each one of the constructs is presented in table 4.

Table 4. Distribution of the answers

\begin{tabular}{|c|c|c|c|c|c|}
\hline Question & $\begin{array}{c}\text { Fully } \\
\text { disagree }\end{array}$ & Disagree & Neutral & Agree & Fully agree \\
& & & & & \\
\hline \multirow{2}{*}{ P1 - cost strategy } & $0 \%$ & $7 \%$ & $26 \%$ & $44 \%$ & $22 \%$ \\
\cline { 2 - 5 } & 0 & 2 & 7 & 12 & 6 \\
\hline \multirow{2}{*}{ P2 - differentiation strategy } & $0 \%$ & $0 \%$ & $11 \%$ & $44 \%$ & $44 \%$ \\
\cline { 2 - 5 } & 0 & 0 & 3 & 12 & 12 \\
\hline \multirow{2}{*}{ P3 - Specialization strategy } & $4 \%$ & $0 \%$ & $7 \%$ & $67 \%$ & $22 \%$ \\
\cline { 2 - 6 } & 1 & 0 & 2 & 18 & 6 \\
\hline P4 - New product development & $4 \%$ & $7 \%$ & $19 \%$ & $37 \%$ & $33 \%$ \\
\cline { 2 - 6 } & 1 & 2 & 5 & 10 & 9 \\
\hline P5 - Value for money strategy & $0 \%$ & $19 \%$ & $19 \%$ & $48 \%$ & $15 \%$ \\
\hline
\end{tabular}

DOI: 10.2478/picbe-2019-0002,pp. 1-12, ISSN 2558-9652| Proceedings of the $13^{\text {th }}$ International Conference on Business Excellence 2019 


\begin{tabular}{|c|c|c|c|c|c|}
\hline & $\mathbf{0}$ & 5 & 5 & 13 & 4 \\
\hline \multirow[t]{2}{*}{ P6 - Competition has increased } & $\mathbf{0 \%}$ & $4 \%$ & $11 \%$ & $37 \%$ & $48 \%$ \\
\hline & $\mathbf{0}$ & 1 & 3 & 10 & 13 \\
\hline \multirow[t]{2}{*}{ P7 - Instability has increased } & $\mathbf{0 \%}$ & $15 \%$ & $26 \%$ & $26 \%$ & $33 \%$ \\
\hline & $\mathbf{0}$ & 4 & 7 & 7 & 9 \\
\hline \multirow[t]{2}{*}{ P8 - Activity sector growth } & $7 \%$ & 0\% & $22 \%$ & $37 \%$ & $33 \%$ \\
\hline & 2 & $\mathbf{0}$ & 6 & 10 & 9 \\
\hline \multirow[t]{2}{*}{ P9 - Technological changes } & $4 \%$ & $\mathbf{0 \%}$ & $22 \%$ & $37 \%$ & $37 \%$ \\
\hline & 1 & $\mathbf{0}$ & 6 & 10 & 10 \\
\hline \multirow[t]{2}{*}{ P10 - Optimistic perspectives } & $\mathbf{0 \%}$ & $4 \%$ & $11 \%$ & $59 \%$ & $26 \%$ \\
\hline & $\mathbf{0}$ & $\mathbf{1}$ & 3 & 16 & 7 \\
\hline \multirow[t]{2}{*}{ P11 - Logistic cost relevance } & $0 \%$ & $4 \%$ & $30 \%$ & $22 \%$ & $44 \%$ \\
\hline & $\mathbf{0}$ & 1 & 8 & 6 & 12 \\
\hline \multirow[t]{2}{*}{ P12 - Profitability growth } & $\mathbf{0 \%}$ & $7 \%$ & $22 \%$ & $44 \%$ & $26 \%$ \\
\hline & $\mathbf{0}$ & 2 & 6 & 12 & 7 \\
\hline \multirow[t]{2}{*}{ P13 - Positive profitability } & $\mathbf{0 \%}$ & $15 \%$ & $15 \%$ & $41 \%$ & $30 \%$ \\
\hline & $\mathbf{0}$ & 4 & 4 & 11 & 8 \\
\hline \multirow[t]{2}{*}{ P14 - Profitability growth expectations } & 0\% & 0\% & $30 \%$ & $26 \%$ & $44 \%$ \\
\hline & $\mathbf{0}$ & $\mathbf{0}$ & 8 & 7 & 12 \\
\hline \multirow[t]{2}{*}{ P15 - Revenue growth } & $0 \%$ & $7 \%$ & $19 \%$ & $48 \%$ & $26 \%$ \\
\hline & $\mathbf{0}$ & 2 & 5 & 13 & 7 \\
\hline \multirow[t]{2}{*}{ P16 - New customers growth } & $\mathbf{0 \%}$ & $4 \%$ & $30 \%$ & $44 \%$ & $22 \%$ \\
\hline & $\mathbf{0}$ & 1 & 8 & 12 & 6 \\
\hline \multirow[t]{2}{*}{ P17 - New markets growth } & $7 \%$ & $11 \%$ & $37 \%$ & $33 \%$ & $11 \%$ \\
\hline & 2 & 3 & 10 & 9 & 3 \\
\hline \multirow[t]{2}{*}{ P18 - Cost reductions achievements } & 0\% & $7 \%$ & $33 \%$ & $44 \%$ & $15 \%$ \\
\hline & $\mathbf{0}$ & 2 & 9 & 12 & 4 \\
\hline \multirow{2}{*}{$\begin{array}{c}\text { P19 - Competitive position } \\
\text { improvement }\end{array}$} & $0 \%$ & $4 \%$ & $44 \%$ & $26 \%$ & $26 \%$ \\
\hline & $\mathbf{0}$ & 1 & 12 & 7 & 7 \\
\hline \multirow{2}{*}{$\begin{array}{l}\text { P20 - Competitive position favorable } \\
\text { versus competitors }\end{array}$} & $0 \%$ & $7 \%$ & $33 \%$ & $41 \%$ & $19 \%$ \\
\hline & $\mathbf{0}$ & 2 & 9 & 11 & 5 \\
\hline \multirow[t]{2}{*}{ P21 - Cooperation with R\&D centers } & $15 \%$ & $19 \%$ & $15 \%$ & $33 \%$ & $19 \%$ \\
\hline & 4 & 5 & 4 & 9 & 5 \\
\hline \multirow{2}{*}{$\begin{array}{l}\text { P22 - Impact of workers qualifications } \\
\text { and salaries in the organization } \\
\text { competitive position }\end{array}$} & $\mathbf{0 \%}$ & $4 \%$ & $19 \%$ & $44 \%$ & $33 \%$ \\
\hline & $\mathbf{0}$ & 1 & 5 & 12 & 9 \\
\hline \multirow{2}{*}{$\begin{array}{l}\text { P23 - Relevance of assess to banking } \\
\text { finance }\end{array}$} & $11 \%$ & $7 \%$ & $11 \%$ & $48 \%$ & $22 \%$ \\
\hline & 3 & 2 & 3 & 13 & 6 \\
\hline \multirow{2}{*}{$\begin{array}{l}\text { P24 - Relevance of government } \\
\text { incentive support }\end{array}$} & $4 \%$ & $15 \%$ & $30 \%$ & $33 \%$ & $15 \%$ \\
\hline & 1 & 4 & 8 & 9 & 4 \\
\hline \multirow{2}{*}{$\begin{array}{l}\text { P } 25 \text { - Relevance of innovation, } \\
\text { response time and flexibility for our } \\
\text { competitiveness }\end{array}$} & $\mathbf{0 \%}$ & $\mathbf{0 \%}$ & $\mathbf{0 \%}$ & $48 \%$ & $52 \%$ \\
\hline & $\mathbf{0}$ & $\mathbf{0}$ & $\mathbf{0}$ & 13 & 14 \\
\hline
\end{tabular}

PICBE | 7 
P26 - Relevance of automotive industry cluster for our competitiveness

\begin{tabular}{|c|c|c|c|c|}
\hline $\mathbf{4 \%}$ & $\mathbf{1 9 \%}$ & $\mathbf{3 0 \%}$ & $\mathbf{3 0 \%}$ & $\mathbf{1 9 \%}$ \\
\hline $\mathbf{1}$ & $\mathbf{5}$ & $\mathbf{8}$ & $\mathbf{8}$ & $\mathbf{5}$ \\
\hline \multicolumn{4}{|c|}{ Source: Authors' own research } \\
\hline
\end{tabular}

The descriptive statistics of the sample confirms that the distribution of the characteristic variables under study (size, activity sector, etc.) coincides with the distribution of the same characteristic variables of AFIA - Portuguese Manufacturers Association for the Automotive Industry associated automobile companies (AFIA, 2017), the base population of this study, which allows to infer that the sample is representative of the population.

As mentioned in the methodology section, the ordinal data was transformed into continuous quantitative data using SPSS software and the Ridits method formula. Table 5, presents the results of the PCA analysis (all main components extracted in each of the constructs, as well as the KMO value) and of the Cronbach Alpha tests (for the extracted variables). The Component column indicates the numerical identification, and characteristic of each component. In other words, each component received a characteristic identification, according to the variables that compose it. For example, component 1 was identified as a "Volume Strategy" as it grouped the variables, "Our strategy for achieving competitive advantage is based on minimizing costs" and "Our strategy for achieving competitive advantage is based in the value of the product/service at minimum cost".

Table 5. PCA, KMO and Cronbach Alpha Results

\begin{tabular}{|c|c|c|c|c|}
\hline Construct & Component & Variables & $\begin{array}{l}\text { KMO } \\
\text { value }\end{array}$ & $\begin{array}{l}\alpha \text { (Cronbach } \\
\text { Alpha value) }\end{array}$ \\
\hline \multirow[t]{2}{*}{ C1- Strategy } & 1- Volume Strategy & P1, P5 & \multirow{2}{*}{0.44} & \\
\hline & $\begin{array}{l}\text { 2- Differentiation/ } \\
\text { focalization strategy }\end{array}$ & P2, P3, P4 & & 0.737 \\
\hline \multirow[t]{2}{*}{$\begin{array}{l}\text { C1.2- Specific } \\
\text { characteristics }\end{array}$} & $\begin{array}{l}\text { 3- Relationship with external } \\
\text { organizations }\end{array}$ & P6, P7, P8, P9, P11 & \multirow{2}{*}{0.54} & 0.375 \\
\hline & $\begin{array}{l}\text { 4- Internal competencies (R\&D, } \\
\text { flexibility, speed,...) }\end{array}$ & P10 & & - \\
\hline \multirow[t]{2}{*}{$\begin{array}{ll}\text { C2.1- } & \text { External } \\
\text { context } & \end{array}$} & $\begin{array}{lr}\text { 5- Positive } & \text { perspective } \\
\text { concerning the } & \text { External } \\
\text { Environment } & \\
\end{array}$ & P14, P15, P16 & \multirow[b]{2}{*}{0.46} & 0.651 \\
\hline & $\begin{array}{lr}\text { 6- Negative } & \text { perspective } \\
\text { concerning the } & \text { External } \\
\text { Environment } & \end{array}$ & P12, P13, P17 & & 0.454 \\
\hline \multirow[t]{3}{*}{$\begin{array}{l}\text { C3.1- Organizational } \\
\text { performance }\end{array}$} & 7- Increasing business results & $\begin{array}{l}\text { P18, P19, P20, P21, } \\
\text { P22, P23, P265 }\end{array}$ & \multirow{3}{*}{0.588} & 0.804 \\
\hline & $\begin{array}{ll}\text { 8- Increased } & \text { competitive } \\
\text { position } & \\
\end{array}$ & P25 & & - \\
\hline & $\begin{array}{l}\text { 9- Positive results in cost } \\
\text { reduction }\end{array}$ & P24 & & - \\
\hline
\end{tabular}

Source: Authors' own research

DOI: 10.2478/picbe-2019-0002, pp. 1-12, ISSN 2558-9652| Proceedings of the $13^{\text {th }}$ International Conference on Business Excellence 2019 
As stated before, the it was adopted an acceptance criterion of above 0.50 for KMO (Aaker, Kumar, \& Day, 2001) and of Cronbach Alpha greater than 0.5 (Davis, 1964). It is also possible to say that some of the extracted components do not have a value of $\alpha$. This is because the component is the variable itself and so there is no way to evaluate the internal consistency by the existence of only one variable absorbed by the component.

The next step within the adopted methodology was to apply the Shapiro-Wilk test to check the normality of the variables. The results for all the 9 components are presented in table 6 , and all have $\mathrm{p}$ values higher than 0.05 , so the null hypothesis (the data comes from a normal distribution).

Table 6. Shapiro-Wilk normality tests

\begin{tabular}{|l|c|}
\hline \multicolumn{1}{|c|}{ Component } & P-value \\
\hline 1- Volume Strategy & 0.257 \\
\hline 2- Differentiation/focalization strategy & 0.650 \\
\hline 3- Relationship with external organizations & 0.404 \\
\hline 4- Internal competencies (R\&D, flexibility, speed,...) & 0.131 \\
\hline $\begin{array}{l}\text { 5- Positive perspective concerning the External } \\
\text { Environment }\end{array}$ & 0.830 \\
\hline $\begin{array}{l}\text { 6- Negative perspective concerning the External } \\
\text { Environment }\end{array}$ & 0.456 \\
\hline 7- Increasing business results & 0.688 \\
\hline 8- Increased competitive position & 0.420 \\
\hline 9- Positive results in cost reduction & 0.852 \\
\hline
\end{tabular}

Once the variables follow a normal distribution, it was decided to perform the correlation analysis with the Pearson coefficient. The positive results of the Pearson correlations and the corresponding p-values are presented in Table 7.

Table 7. Positive results of the Pearson correlations and $p$ values

\begin{tabular}{|c|c|c|c|}
\hline Component 1 & Component 2 & Pearson Correlation & p-value \\
\hline $\begin{array}{c}\text { 2- Differentiation/ } \\
\text { focalization strategy }\end{array}$ & $\begin{array}{c}\text { 7- Increasing business } \\
\text { results }\end{array}$ & 0.362 & 0.026 \\
\hline $\begin{array}{c}\text { 5- Positive perspective } \\
\text { concerning the } \\
\text { External Environment }\end{array}$ & $\begin{array}{c}\text { 8- Increased } \\
\text { competitive position }\end{array}$ & 0.381 & 0.050 \\
\hline
\end{tabular}

Source: Authors' own research

For the correlation analyzes according to the Pearson coefficient, there are two positive and weak correlations that were validated by test values less than or equal to $5 \%$, thus rejecting the null hypothesis and accepting hypothesis 1 , that is, the correlation coefficient is different from zero.

\section{Conclusion}

This investigation suffers from the limitations of the small sample size (27 valid individuals). Concerning the validation of the main components extracted, the values of the KMO index are 
at the threshold of the acceptable, and for the Cronbach's Alpha values, applying Davis's (Davis, 1964), three components were obtained in nine, with a value lower than 0.5.

Based on the correlation analysis performed, according to the Shapiro-Wilk test, all extracted components follow a normal distribution, thus allowing the use of the Person coefficient. The results indicate that companies following a strategy based on differentiation/ focalization see improved business (sales volume, profitability) results.

PICBE | 10

Also, firms that consider that the external environment is favorable also see improved business results. Only two of the three proposed hypotheses have been confirmed:

- H1 (Strategy influences Value Creation), since the correlation results show that the differentiation/focalization strategy evolves in the same sense as the growing business and financial results. The organization's strategy influences its performance through the creation of value. On the other hand, there is no evidence to state that the adoption of a volume strategy penalizes the performance of the organization.

- H2 (Specific Characteristics influence Value Creation), no significant correlation was found. Therefore, this research hypothesis remains unanswered.

- The correlation results confirm H3 (External Context influences Value Creation), the external (positive) context also seems to influence the creation of (higher) value for the business.

These conclusions are in line with those obtained by Fonseca and Domingues (2017) that emphasize the importance of the external organizational context and the innovation and capacity for change (requirements for the differentiation/focalization strategies) for value creation in the automotive industry and confirm the Porter competitive advantage theory (Porter, 1985).

Given the relevance of the automotive industry (components, tools, and services providers) firms for the Portuguese Gross Domestic Product and national employment, these conclusions are of significant interest, by highlighting the value of adopting a differentiation strategy, therefore, investing in Research and Development and Branding, or pursuing a focalization strategy, focusing on market niches, with the aim of achieving enduring business performance. Also, automotive industry firms need to monitor the external environment and take advantage of significant opportunities.

As acknowledged before, this investigation suffers from the limitation of the small sample size. Besides, since the survey is based on the perceptions of the respondents, it might be subject to potential response bias. Some of the proposals for future work may be to test other research hypotheses, considering other variables that have not used in this investigation, such as, size of the organization (number of employees), certifications, seniority of the organization and sector of activity. It would also be interesting to resubmit the questionnaire and reach a larger sample, since the more significant the sample, the stronger the characterization of the population should be.

\section{References}

Aaker, D., Kumar, V., \& Day, G. (2001). Pesquisa de Marketing. São Paulo: Editora Atlas. ACAP. (2016). Veículos automóveis produzidos em Portugal. Associação Automóvel de Portugal. 
AFIA. (2017). PORTUGAL- Indústria de Componentes para Automóveis. Retrieved from http://www.afia.pt/images/stories/pdf2017/afia_autocomponentsindustry_uk_201 70525.pdf.

Bross, I. D. (1958). How to Use Ridit Analysis. Biometrics, 14 (1), 18-38.

Cronbach LJ. (1951). Coefficient alpha and the internal structure of tests. Psychometrika, $16,297-334$

Davis, F. B. (1964). Educational measurements and their interpretation. California: Wadsworth Publishing Co.

Demeter, K. (2003). Manufacturing strategy and competitiveness. International Journal of Production Economics, 81-82, 2015-213.

Fonseca L.M, Domingues J.P. (2017a). Reliable and flexible Quality Management Systems in the automotive industry: monitor the context and change effectively. Procedia Manufacturing, 11C, 1200-1206.

Fonseca, L.M. and Domingues, J.P., (2017b). How to succeed in the digital age? Monitor the organizational context, identify risks and opportunities, and manage change effectively. Management \& Marketing. Challenges for the Knowledge Society, 12 (3), 443-455.

Ghauri, P. K., \& Gronhaug, K. (2002). Research Methods in business studies: A practical guide. Harlow U.K.: Financial Times, Prentice Hall.

Gower, J. C. (1967). Multivariate analysis and multidimensional geometry. Statistician, 17, 13-28.

Hinkle, D. E., Wiersma, W., \& Jurs, S. (2003). Applied Statistics for the Behavioral Sciences 5th ed. Boston: Houghton Mifflin.

Hotelling, H. (1993). Analysis of a complex of statistical variables into principal components. Journal of Educational Psychology, 24, 417-441.

Jeffers, J. N. (1967). Two case studies in the application of principal component analysis. Applied Statistics, 16, 225-236.

Kao, C., Wu, W. Y., Hsieh, W. J., Wang, T. Y., Lin, C., \& Chen, L. H. (2008). Measuring the national competitiveness of Southeast Asian countries. European Journal of Operational Research, 187(2), 613-628.

Lee, C., \& Wilhelm, W. (2010). On integrating theories of international economics in the strategic planning of global supply chains and facility location. International Journal of Production Economics, 124 (1), 225-240.

Lucato, W. C., Juníor, M. V., Vanalle, R. M., \& Arantes, J. A. (2012). Model to measure the degree of competitiveness for auto parts manufacturing companies. International Journal of Production Research, 50 (19), 5508-5522.

Oral, M., \& Reisman, A. (1988). Measuring industrial competitiveness. Industrial Marketing Management, 17(3), 263-272.

Pearson, K. (1901). On lines and planes of closest fit to systems of points in space. Philosophical Magazine, 2 (6), 559-572.

Porter, M. (1985). Competitive advantage: Creating and Sustaining Superior Performance. New York: Free Press Edition.

Porter, M. E. (1990). The Competitive Advantage of Nations. New York: Free Press. 
Rao, C. R. (1964). The use and interpretation of principal component analysis in applied research. Sankhya A, 26, 329-358.

Sala-i-Martin, X., Bilbao-Osorio , B., Blanke, J., Crotti, R., Hanouz, M., Geiger, T., \& Ko, C. (2012). The global competitiveness index 2012-2013: Strengthening recovery by raising productivity. In: World economic forum. The global competitiveness report 2012-2013 (pp. 3-48).

Shapiro, S. S., \& Wilk, M. (1965). An analysis of variance Test for Normality. Biometrika, 52, 591-611.

Statista. (2016). Retrieved from https://www.statista.com/statistics/269619/automotivesuppliersshareofworldwid eautomobilemanufacturesince1985/.

Ulengin, A. F., Onsel, B. S., Aktas, C. E., Kabak, D. O., \& Ozaydın, B. O. (2014). A decision support methodology to enhance the competitiveness of the Turkish automotive industry. European Journal of Operational Research, 234, 789-801.

Worldwathch, (2017). Retrieved from http://vitalsigns.worldwatch.org/vs-trend/autoproduction-sets-new-record-fleet-surpasses-1-billion-mark. 